\title{
Antioxidant activity of camel and bovine milk fermented by lactic acid bacteria isolated from traditional fermented camel milk (Chal)
}

\author{
Nazila Soleymanzadeh ${ }^{1} \cdot$ Saeed $_{\text {Mirdamadi }}{ }^{1}$. \\ Mehran Kianirad ${ }^{1}$
}

Received: 5 October 2015 /Revised: 11 January 2016 / Accepted: 15 January 2016 /

Published online: 1 February 2016

C) INRA and Springer-Verlag France 2016

\begin{abstract}
Chal is a traditional fermented product produced from spontaneously fermented camel milk which contains several bacterial species with potential usage in producing traditional dairy products and functional foods. The aims of this study were to isolate and identify predominant lactic acid bacteria (LAB) from Chal and investigate antioxidant activity of camel and bovine milk fermented by these isolates. Chal samples were collected from Turkman Sahra, Golestan Province, Iran. The protein hydrolysis was determined by o-phthaldialdehyde (OPA) method, and antioxidant activities of whey fractions were evaluated by 1,1-diphenyl-2-picrylhydrazyl (DPPH) and 2,2'azinobis(3-ethylbenzothiazoline-6-sulfonic acid) (ABTS) free radicals scavenging methods. Nine catalase-negative bacteria including Lactobacillus (L.) plantarum, L. paraplantarum, L. kefiri, L. gasseri, L. paracasei, Leuconostoc (Leu.) lactis, Weissella (W.) cibaria, and Enterococcus (E.) faecium were isolated and identified by conventional and molecular methods. Both camel and bovine milk were fermented by the strains for $24 \mathrm{~h}$. Fermented camel milk showed significantly $(P<0.05)$ higher antioxidant activity than bovine milk. Camel milk fermented by Leu. lactis showed significantly $(P<0.05)$ higher DPPH $(57.90 \pm 4.59 \mu \mathrm{M})$ and ABTS $(1484.35$ $\pm 128.20 \mu \mathrm{M} ; P<0.05)$ radical scavenging activity compared to samples fermented by other strains. According to sensory evaluation of fermented camel and bovine milks, camel milk fermented by Leu. lactis SM10 had the highest overall acceptance values. Our findings suggest that camel and bovine milk fermented by LAB isolated from Chal could potentially be used for producing novel functional foods.
\end{abstract}

Keywords Antioxidant activity $\cdot$ Camel milk $\cdot$ Chal $\cdot$ Fermented milk $\cdot$ LAB

Saeed Mirdamadi

Mirdamadi@irost.ir

1 Department of Biotechnology, Iranian Research Organization for Science and Technology, TehranP.O. Box 3353-51111, Iran 


\section{Introduction}

Chal is a kind of fermented camel milk and a candidate for usage as a functional food. It is traditionally produced using spontaneous fermentation in Turkman Sahra, Golestan province, Iran. Chal and Chal-like products are known under different names in other countries such as Shubat in Kazakhstan and Turkmenistan in central Asia. Chal is typically prepared by fermentation of camel milk, by adding the previously fermented acidic milk as inoculums, in earthenware jug for 1 or 2 days depending on the season of the production in Iran. Local producers use spontaneous fermentation of milk that results in variable product quality. Accordingly, using lactic acid bacteria (LAB) strains to improve fermentation under controlled conditions is an important step in producing camel fermented milk (Moslehishad et al. 2013b).

Milk proteins are considered as the most important source of a broad range of biologically active compounds (Agamy 2009). Bioactive peptides with various activities can be generated during milk fermentation with LAB (Korhonen and Pihlanto 2006; Mills et al. 2011). The antioxidant properties demonstrated in fermented bovine and camel milk suggest that beside their nutritional value, they are also potential candidates for functional and novel foods to improve health through nutrition (Korhonen 2009). A broad range of natural bioactive peptides have been found in fermented dairy products, such as yoghurt, sour milk, and cheese (Fitzgerald and Murray 2006). Beneficial health effects of these peptides include immunomodulatory activities, antioxidative activities (Parrella et al. 2012; Solieri et al. 2015), antimicrobial (Hernandez et al. 2005), opioid (Pihlanto-Leppälä 2000) mineral binding (Lorenzen and Meisel 2005), and ACE inhibitory activities (Yamamoto and Takano 1999; Gobbetti et al. 2004). Radical scavenging is the main mechanism by which antioxidants act in foods. Recently, Moslehishad et al. (2013a) demonstrated that fermentation of camel milk with single strains of LAB generated antioxidant activity in the whey fractions. On the other side, it is well documented that bovine milk fermented with proteolytic strains of LAB contains health-promoting bioactive peptides (Fitzgerald and Murray 2006). In the literature, there is not enough information about bacterial flora and functional properties of the Iranian traditional fermented camel milk (Chal). Therefore, the aim of this study was to isolate wild strains of LAB from Chal and compare their antioxidant activities during the fermentation of camel and bovine milk to produce new functional foods.

\section{Materials and methods}

\subsection{Materials}

Camel milk and Chal samples were collected from local camel milk producers in Turkman Sahra, Golestan Province, Iran. Ultra-high temperature (UHT) bovine milk was purchased from Kalleh Dairy Company in Tehran, Iran. All of the milk samples were stored at $4{ }^{\circ} \mathrm{C}$ during transportation to the laboratory. 2,2'-Azinobis(3-ethylbenzothiazoline-6-sulfonic acid) (ABTS) radical, 1,1-diphenyl-2-picrylhydrazyl (DPPH) radical, 6-hydroxy-2,5,7,8-tetramethylchroman-2-carboxylic acid (Trolox), and orthophtaldehyde (OPA) were obtained from Sigma-Aldrich chemie GmbH (Munich, Germany) and bovine serum albumin (BSA) was from Merck, Darmstadt, Germany. 


\subsection{Milk analysis}

Bovine and camel milk samples were analyzed for Crude protein (CP) using AOAC method No. 998.05 (AOAC 2002), milk fat and lactose by a mid-infrared analyzer (Milko-Scan S50; Foss Electric, Hillerød, Denmark), according to AOAC No. 972.16 (AOAC 2002), total solids (TS) by calculation (fat + Solid Not Fat (SNF)), pH with a potentiometer, and titratable acidity (TA) according to the titrimetric method of AOAC No. 947.05 (AOAC 2002).

\subsection{Isolation of lactic acid bacteria}

Ten Chal samples were collected from local camel milk producers in Turkman Sahra, Golestan Province, Iran, during June and July, 2012. Raw camel milk samples were collected from local producers monthly except camels' mating season. One gram of each sample was added to $9 \mathrm{~mL}$ of $0.85 \%$ physiological serum, and appropriate dilution was spread plated on de Man, Rogosa, and Sharpe (MRS) agar plates containing $50 \mathrm{mg} . \mathrm{L}^{-1}$ nistatin for inhibiting the yeast growth. Plates were incubated anaerobically in candle jar at $37 \pm 1{ }^{\circ} \mathrm{C}$ for $48 \mathrm{~h}$. Colonies with different morphologies were subcultured again on MRS agar plates for checking the purity. Forty-one isolates were obtained and nine of them were catalase-negative. Isolates were preserved at $-80{ }^{\circ} \mathrm{C}$, in MRS broth using $15 \%(v / v)$ glycerol.

\subsection{Conventional and molecular identification of LAB strains}

Identification of the isolates was performed by biochemical tests such as catalase activity and determination of carbohydrate fermentation and characterized taxonomically according to the criteria described in Bergey's Manual (Kandler and Weiss 1986). Each isolate was tested for the ability to ferment carbohydrates. Molecular identification of the isolates was carried out using 16S rRNA sequence analysis. Differentiation of Lactobacillus (L.) plantarum/L. pentosus/L. paraplantarum group species was performed by amplification of recA gene. The primers used were paraF (59-GTC ACA GGC ATT ACG AAA AC-39), pentF (59-CAG TGG CGC GGT TGA TAT C-39), planF (59-CCG TTT ATG CGG AAC ACC TA-39), and pREV (59-TCG GGA TTA CCA AAC ATC AC-39) reported by Torriani et al. (2001).

\subsection{Fermentation of milk by isolated LAB strains}

The organisms were activated in sterile 5-mL aliquots of MRS broth at $37^{\circ} \mathrm{C}$ for $24 \mathrm{~h}$. Then, $1 \mathrm{~mL}$ of each culture was added to $10-\mathrm{mL}$ sterile aliquots of MRS broth and incubated at $37^{\circ} \mathrm{C}$ for $24 \mathrm{~h}$ as preculture to obtain approximately $10^{8}$ colony-forming units (cfu). $\mathrm{mL}^{-1}$. The cultures were centrifuged at $5000 \times \mathrm{g}$ for $15 \mathrm{~min}$ to separate the bacteria. The biomass was then inoculated into UHT bovine and pasteurized $\left(70{ }^{\circ} \mathrm{C}\right.$ for $20 \mathrm{~min}$ ) camel milk to obtain approximately $10^{7} \mathrm{cfu} . \mathrm{mL}^{-1}$ as inoculums and incubated at $37^{\circ} \mathrm{C}$ for $24-48 \mathrm{~h}$. Aliquots $(5 \mathrm{~mL})$ of each sample were taken to determine $\mathrm{pH}$ and TA during the fermentation.

After $24 \mathrm{~h}$ of fermentation, cell population of the bacteria was determined by counting colony-forming units (cfu) on MRS agar at $37^{\circ} \mathrm{C}$ for $48 \mathrm{~h}$ in candle jar under 
enriched $\mathrm{CO}_{2}$. The whey fraction of the fermented bovine and camel milk was separated by adjusting $\mathrm{pH}$ at 4.6 and centrifugation at $20,000 \times \mathrm{g}$ for $20 \mathrm{~min}$ and the supernatant stored at $20^{\circ} \mathrm{C}$ for further analysis. Fresh camel and bovine milk without the bacteria were used as control.

\subsection{Characterization of fermented milk samples}

The protein contents of the samples were measured by Lowry method modified by Hartree (1972), and bovine serum albumin was used as a standard. The proteolytic activity was determined with the OPA method described by Church et al. (1983). Lleucine was used as a standard. The sample was mixed with $1 \mathrm{~mL}$ of OPA reagent, and after 2-min incubation at room temperature, the absorbance was measured with a spectrophotometer at $340 \mathrm{~nm}$ (PG Instraments Ltd., model T80+).

\subsection{Determination of antioxidant activity}

\subsubsection{DPPH radical scavenging activity}

The antioxidant activity was evaluated by the DPPH radical scavenging activity described by Son and Lewis (2002). DPPH radical solution $(0.002 \%, w / v)$ in $95 \%$ ethanol was prepared. A volume of $1800 \mu \mathrm{L}$ of DPPH in ethanol was added to $200 \mu \mathrm{L}$ of whey fraction with the concentration of $1 \mathrm{mg} \cdot \mathrm{mL}^{-1}$, well vortexed and incubated for $30 \mathrm{~min}$ in dark room at room temperature. Absorbance of each sample at $517 \mathrm{~nm}$ was measured using UV-Visible spectrophotometer (PG Instruments Ltd., model T80+). Ethanol was used as a blank, while DPPH solution in ethanol served as control. The antioxidant activity was expressed as percentage of DPPH activity calculated as

$$
\% \text { Inhibition }=\left[\frac{\text { Absorbance } 517 \text { Blank-Absorbance } 517 \text { sample }}{\text { Absorbance } 517 \text { Blank }}\right] \times 100 \%
$$

The Trolox standard curve was used for determination of Trolox equivalent antioxidant capacity (TEAC).

\subsubsection{ABTS radical scavenging activity}

The scavenging of ABTS radical by the whey fractions was assayed by a method described by Re et al. (1999). One milliliter of diluted ABTS radical solution in $5 \mathrm{mmol} . \mathrm{L}^{-1}$ of phosphate-buffered saline (PBS) was added to $25 \mu \mathrm{L}$ of whey fraction with the concentration of $1 \mathrm{mg} \cdot \mathrm{mL}^{-1}$ and Trolox in ethanol or distilled water (blank), and after $2 \mathrm{~min}$, the absorbance was measured at $734 \mathrm{~nm}$.

$$
\text { \%inhibition }=\frac{\text { Absorbance } 734 \text { Blank-Absorbance } 734 \text { sample }}{\text { Absorbance } 734 \text { Blank }} \times 100 \%
$$

The Trolox standard curve was used for determination of Trolox equivalent antioxidant capacity (TEAC). 


\subsection{Sensory evaluation of fermented milks}

A panel of 20 untrained assessors evaluated the sensory attributes of the fermented camel and bovine milk based on the method developed by International Dairy Federation (Karagul-Yuceer and Drake 2006). The samples were codified and presented to the panelist in randomized order as suggested. Each panel was presented with two groups (camel and bovine milk fermented by six isolates with "Qualified Presumption of Safety" (QPS) status). Each group includes six coded fermented milk samples. They were asked to rinse their mouth with water between each sample testing. The evaluation of the product was carried out on taste, aroma, texture, and overall acceptability on a seven-point hedonic scale by panelists $(0=$ dislike extremely; $7=$ like extremely $)$.

\subsection{Statistical analysis}

All data were subjected to one-way analysis of variance (ANOVA) using SPSS 16.0 software (SPSS INC., Chicago, IL, USA, 2002), and the individual samples were compared (on a 0.05 level of significance) by the Tukey's HSD multiple comparison test.

\section{Results and discussion}

\subsection{Chemical composition of milk}

Chemical composition of camel and bovine milk used in this study was analyzed. Table 1 presents the chemical components of raw camel and bovine milk. Mean value for crude protein (CP) in camel milk was significantly higher than bovine milk $(P<0.05)$. Camel milk contained higher fat, TA, and TS values compared to bovine milk $(P<0.05)$. Yoganandi et al. (2014) reported that the fat, TS, and CP contents in bovine milk were higher than in camel milk. On the other hand, bovine milk had significantly higher lactose content than camel milk $(P<0.05)$. Mean values for fat and lactose content in camel milk were $4.00 \pm 0.20 \mathrm{~g} / 100 \mathrm{~g}$ and $3.44 \pm 0.08 \mathrm{~g} / 100 \mathrm{~g}$ while those reported by Bahobail et al. (2014) were $3.2 \mathrm{~g} / 100 \mathrm{~g}$ and $4.6 \mathrm{~g} / 100 \mathrm{~g}$, respectively. This could be attributed to seasonal variations, feeding conditions, and geographical origin (Yoganandi et al. 2014).

Table 1 Chemical composition (mean + SE) of raw camel and UHT bovine milk

\begin{tabular}{lllllll}
\hline & TA $\left({ }^{\circ} \mathrm{D}\right)$ & $\mathrm{pH}$ & Fat $(\mathrm{g} / 100 \mathrm{~g})$ & Lactose $(\mathrm{g} / 100 \mathrm{~g})$ & $\mathrm{CP}(\mathrm{g} / 100 \mathrm{~g})$ & $\mathrm{TS}(\mathrm{g} / 100 \mathrm{~g})$ \\
\hline Camel milk & $19 \pm 0.09^{\mathrm{b}}$ & $6.47 \pm 0.04^{\mathrm{a}}$ & $4.00 \pm 0.20^{\mathrm{b}}$ & $3.44 \pm 0.08^{\mathrm{a}}$ & $2.84 \pm 0.12^{\mathrm{b}}$ & $11.74 \pm 0.45^{\mathrm{b}}$ \\
Bovine milk & $18 \pm 0.07^{\mathrm{a}}$ & $6.65 \pm 0.03^{\mathrm{b}}$ & $0.85 \pm 0.05^{\mathrm{a}}$ & $4.41 \pm 0.04^{\mathrm{b}}$ & $2.65 \pm 0.09^{\mathrm{a}}$ & $9.80 \pm 0.21^{\mathrm{a}}$ \\
\hline
\end{tabular}

The experiments were done in three replicates. Values with different superscript lowercase letters $(a, b)$ within the same column are significantly different at $P<0.05$

$T S$ total solid, $C P$ crude protein, $T A$ titratable acidity 


\subsection{Conventional and molecular Identification of LAB strains}

The transferred samples at $4{ }^{\circ} \mathrm{C}$ from Golestan Province, Iran, were examined for isolation of microbial population. Nine isolates were obtained, of which five were from Chal samples and four isolates obtained from raw camel milk samples. The isolates were identified by morphological and biochemical tests, according to Bergey's manual (Kandler and Weiss 1986). The isolates were identified by $16 \mathrm{~S}$ rRNA gene sequencing analysis using polymerase chain reaction (PCR). The $16 \mathrm{~S}$ rRNA gene sequences of isolates showed more than $99.8 \%$ similarity to those of the reference strains. Nine isolates were accurately designated to eight species, namely, L. plantarum/L. pentosus/L. paraplantarum (two isolates), L. kefiri, L. gasseri, L. paracasei, Leuconostoc (Leu.) lactis, Weissella (W.) cibaria, and Enterococcus (E.) faecium (two isolates). The two isolates were identified as belonging to the L. plantarum $/ L$. pentosus $/ L$. paraplantarum group which were distinguished by a multiplex PCR based on recA gene sequence analysis. The results showed that one of the isolates belonged to L. plantarum while the other isolate was identified as L. paraplantarum. Among these isolates, E. faecium and W. cibaria are not included in the list of taxonomic units proposed by the European Food Safety Authority (EFSA) for QPS status. Although members of the Lactobacillus genus are daily consumed in large quantities in a variety of fermented foods, there is an increasing number of reports that they might occasionally be involved in human disease and many Lactobacillus species have been occasionally encountered in clinical specimens. However, the clinical significance of which was not always clear (EFSA 2007). An individual examination of all isolates is in progress to ensure the safety of strains.

\subsection{Cell growth and pH changes during the fermentation}

Viable counts of bacteria and $\mathrm{pH}$ changes show growth and activity rate of isolated bacteria. The growth rate and activity of isolated bacteria in both camel and bovine milk were examined by measuring the viable counts and $\mathrm{pH}$ (acid production), respectively. The bacterial counts of fermented camel and bovine milk ranged between 7.30 to 9.04 and 7.17 to $10.17 \log$ cfu. $\mathrm{mL}^{-1}$, respectively, after the $24 \mathrm{~h}$ of fermentation (Fig. 1). The growth rate of $L$. gasseri SM05 and $W$. cibaira SM09 was significantly $(P<0.05)$ lower than the others, while L. plantarum SM06, L. paracasei SM09, and Leu. lactis SM10 showed a significantly higher growth rate in both camel and bovine milks. As expected, all LAB strains showed the ability to acidify camel and bovine milk after $24 \mathrm{~h}$ of fermentation at $37^{\circ} \mathrm{C}$ (Fig. 2), and these can be explained with the ability of LAB to breakdown hexoses to lactic acid (Arici et al. 2004; Parrella et al. 2012; Widyastuti et al. 2014). There was a good relationship between the growth rate of bacteria and $\mathrm{pH}-$ lowering activity so that the bacteria with low growth rate could not reduce $\mathrm{pH}$ contrary to those with high growth rate. As shown in Figs. 1 and 2, the ability of strains to grow in milk and reduce the $\mathrm{pH}$ was different and Leu. lactis SM10 and W. cibaria SM09 showed, respectively, the lowest and highest $\mathrm{pH}$ values in both fermented camel and bovine milk. The reduction of $\mathrm{pH}$ was greater in camel milk than in bovine milk, and as shown in Fig. 2, the final $\mathrm{pH}$ of fermented camel milk samples was less comparing to 


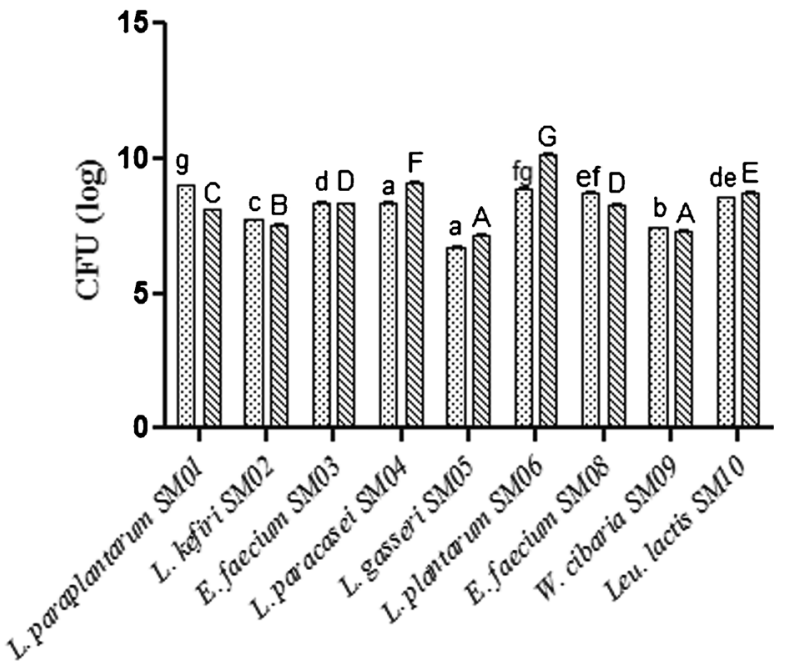

Fig. 1 Population of bacteria in fermented camel (bar with dots) and bovine (bar with lines) milks with LAB strains after $24 \mathrm{~h}$ of fermentation. Error bars show standard error of the mean of triplicate measurements of experiments. Mean values with different small and capital letters for respectively camel and bovine milk are significantly different $(P<0.05)$

fermented bovine milks. This can be explained by lower buffering capacity of fermented camel milk than that of bovine milk (Al haj and Al Kanhal 2010; Al-Saleh and Hammad 1992). The decrease in cell growth observed between 24 and $48 \mathrm{~h}$ in some fermentation batches (data not shown) may be due to the production of lactic acid in media by growing lactic acid bacteria, which can inhibit bacterial growth at high concentrations (Leroy and De Vuyst 2001).

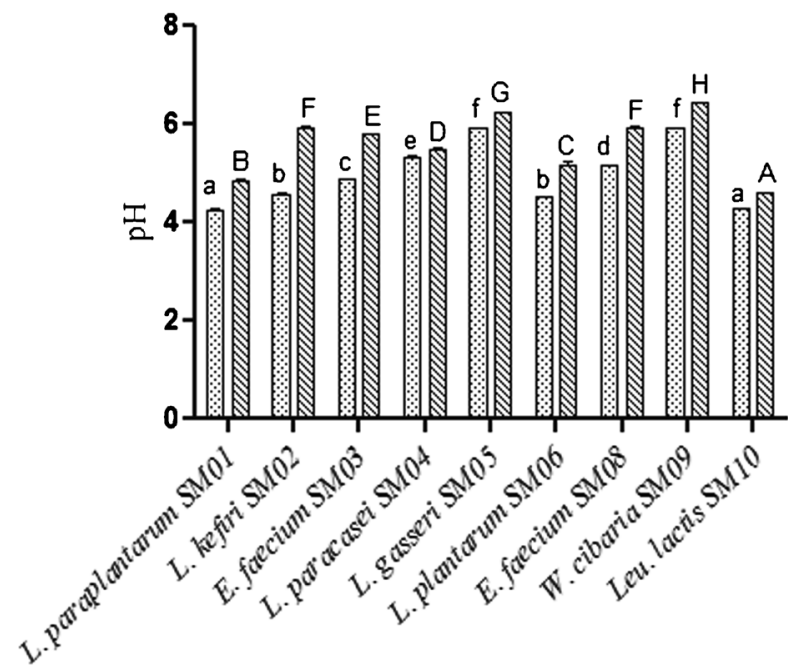

Fig. $2 \mathrm{pH}$ values of fermented camel (bar with dots) and bovine (bar with lines) milks with LAB strains after $24 \mathrm{~h}$ of fermentation. Error bars show standard error of the mean of triplicate measurements of experiments. Mean values with different small and capital letters for respectively camel and bovine milk are significantly different $(P<0.05)$ 


\subsection{Protein hydrolysis in fermented milk}

Peptides are the result of proteolysis of milk proteins by LAB that are necessary for sustained growth of these bacteria in milk (Zhang et al. 2014). A broad range of natural bioactive peptides have been found in fermented dairy products, such as yoghurt, sour milk, and cheese (Fitzgerald and Murray 2006). Protein hydrolysis in fermented milks was determined in fermentation batches after 24 and $48 \mathrm{~h}$ of fermentation (data not shown for $48 \mathrm{~h}$ fermentation). As shown in Fig. 3a, the OPA values in fermented camel milk by L. plantarum SM06 and L.paraplantarum SM01 were significantly higher than the others as also the growth rate of these strains was significantly higher $(P<0.05)$; on

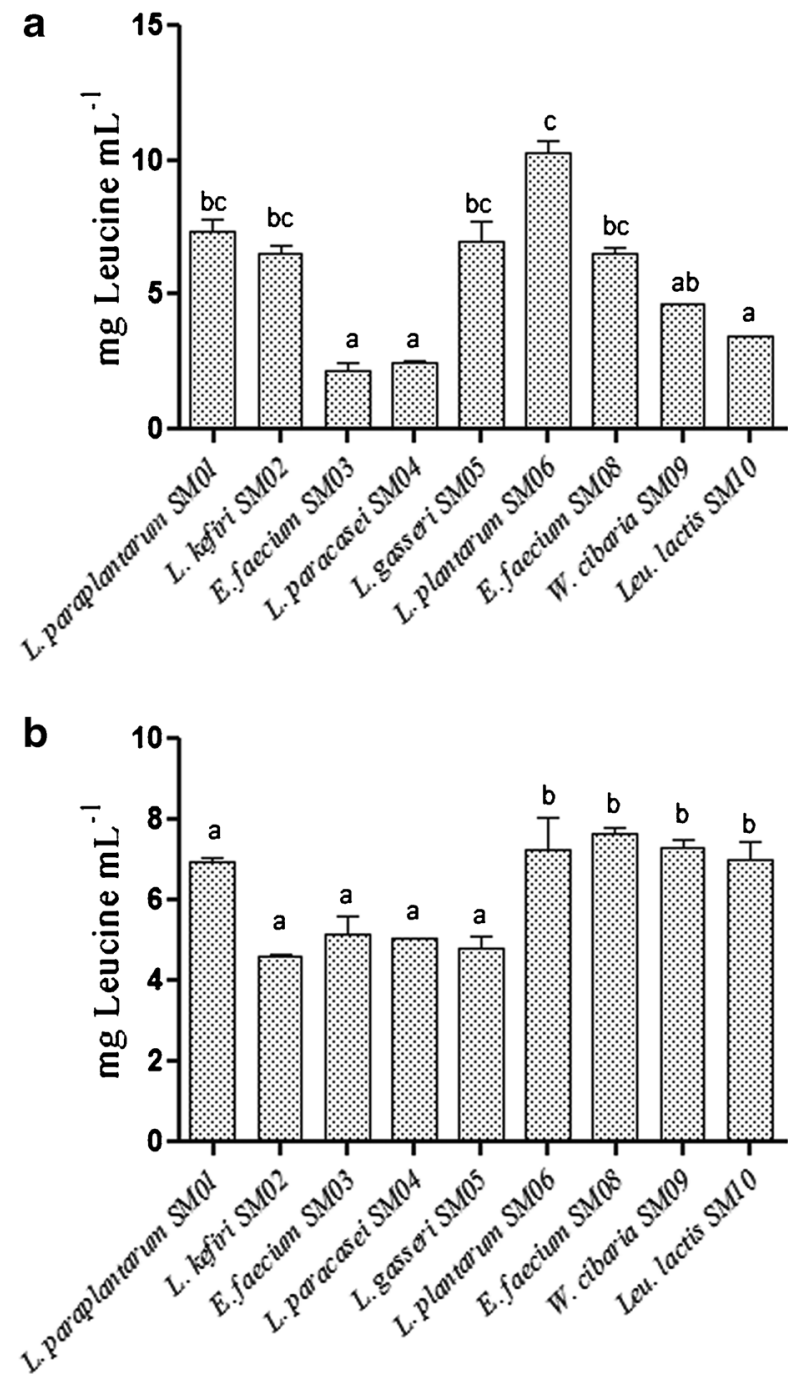

Fig. 3 Proteolytic activity of fermented camel (a) and bovine (b) milks with single strains of lactic acid bacteria after $24 \mathrm{~h}$ of fermentation. Error bars show standard error of the mean of triplicate measurements of experiments. Mean values with different small letters are significantly different $(P<0.05)$ 
the other hand, the OPA values in fermented camel milk by Leu. lactis SM10, E. faecium SM03, and L. paracasei SM04 were significantly lower $(P<0.05)$. In fermented bovine milks, the OPA values were closer to each other and strains Leu. lactis SM10, W. cibaria SM09, E. faecium SM08, L. plantarum SM06, and L. gasseri SM05 significantly showed high protein hydrolysis $(P<0.05)$. These data were consistent with the results reported by Abu-Taraboush et al. (1998) that the rate of proteolysis did not follow the rate of biomass production. As discussed earlier, LAB use free amino acids (FAAs) as growth factors during fermentation since FAA content could be higher in fermentation batches with low growth rate of bacteria (Cheng and Nagasawa 1986). In fermented camel milk samples, proteolysis in most of the cases increased as fermentation time increased (data not shown) that agreed with the data reported by Abu-Tarboush (1996). The results showed that fermented milks by L. kefiri SM02 and L. gasseri SM05 values of protein hydrolysis in camel milk were greater than in bovine milk, while bovine milks fermented by E. faecium SM03, L. paracasei SM04, and Leu. lactis SM10 showed higher proteolytic activity comparing to fermented camel milks. Moslehishad et al. (2013a) reported approximately similar values of proteolytic activity in camel and bovine milks fermented by L. rhamosus. However, the differences might be due to the difference of bacteria and source of the milk used for the study. The differences in the protein hydrolysis by bacteria in both camel and bovine milk could have been attributed to the differences in protein byproducts in camel and bovine milk and the differences among species.

\subsection{Determination of antioxidant activity}

The antioxidant activity of whey fractions from fermented milks by LAB has been mentioned in several studies (Balakrishnan and Agrawal 2014) and expressed in various ways, and the conflicting results have been obtained. In the present study, we evaluated the antioxidant activity of whey fractions of fermented milks against two different ABTS and DPPH radicals. Whey fractions from fermented camel milk showed higher antioxidant activity than in bovine milk based on both ABTS and DPPH assays. These results were consistent with those reported by Moslehishad et al. (2013a) who expressed that peptide fractions from camel milk fermented by L. rhamnosus showed higher antioxidant activity than in bovine milk. This shows that the nature and composition of milk are important factors in antioxidant activity.

Based on ABTS radical scavenging activity, the antioxidant activity of the whey fraction from unfermented camel and bovine milk was 151.83 and $90.21 \mu \mathrm{M}$ TE, respectively. After $24 \mathrm{~h}$ of fermentation in all of the batches, the antioxidant activity of fermented milks increased. Virtanen et al. (2007) reported that the antioxidant activity increased during the fermentation in some of the cases. The antioxidant activity was not directly influenced by protein hydrolysis of the whey fractions as the camel milk fermented by Leu. lactis SM10 with low proteolytic activity (3.44 $\pm 0.04 \mathrm{mg}$ Leu. $\mathrm{mL}^{-1}$ ) showed significantly the highest DPPH radical scavenging activity $(57.90 \pm 4.59 \mu \mathrm{M}$ TE) while the ABTS radical scavenging activity was also high $(1484.35 \pm 128.20 \mu \mathrm{M}$ TE) $(P<0.05)$. In fermented bovine milk samples, Leu. lactis SM10 showed significantly the highest ABTS radical scavenging (311.66 $\pm 1.99 \mu \mathrm{M}$ TE) and protein hydrolysis activity $\left(8.25 \pm 1.62 \mathrm{mg} L e u . \mathrm{mL}^{-1} ; P<0.05\right)$ while the DPPH radical scavenging activity was not significantly higher than others. It 
can therefore be concluded that specifications of the proteolytic enzymes of bacterial strains are more effective on the radical scavenging activity comparing to high proteolytic state of fermented product (Virtanen et al. 2007).

As shown in Figs. 4 and 5, the whey fractions from both fermented camel and bovine milks exhibited much lower antioxidant capacities as measured by DPPH assay relative to ABTS assay. This may be because of different radical scavenging mechanisms and sensitivity of two assay methods in hydrophilic and lipophilic antioxidant systems. The same results were previously reported by Mirzaei et al. (2015).

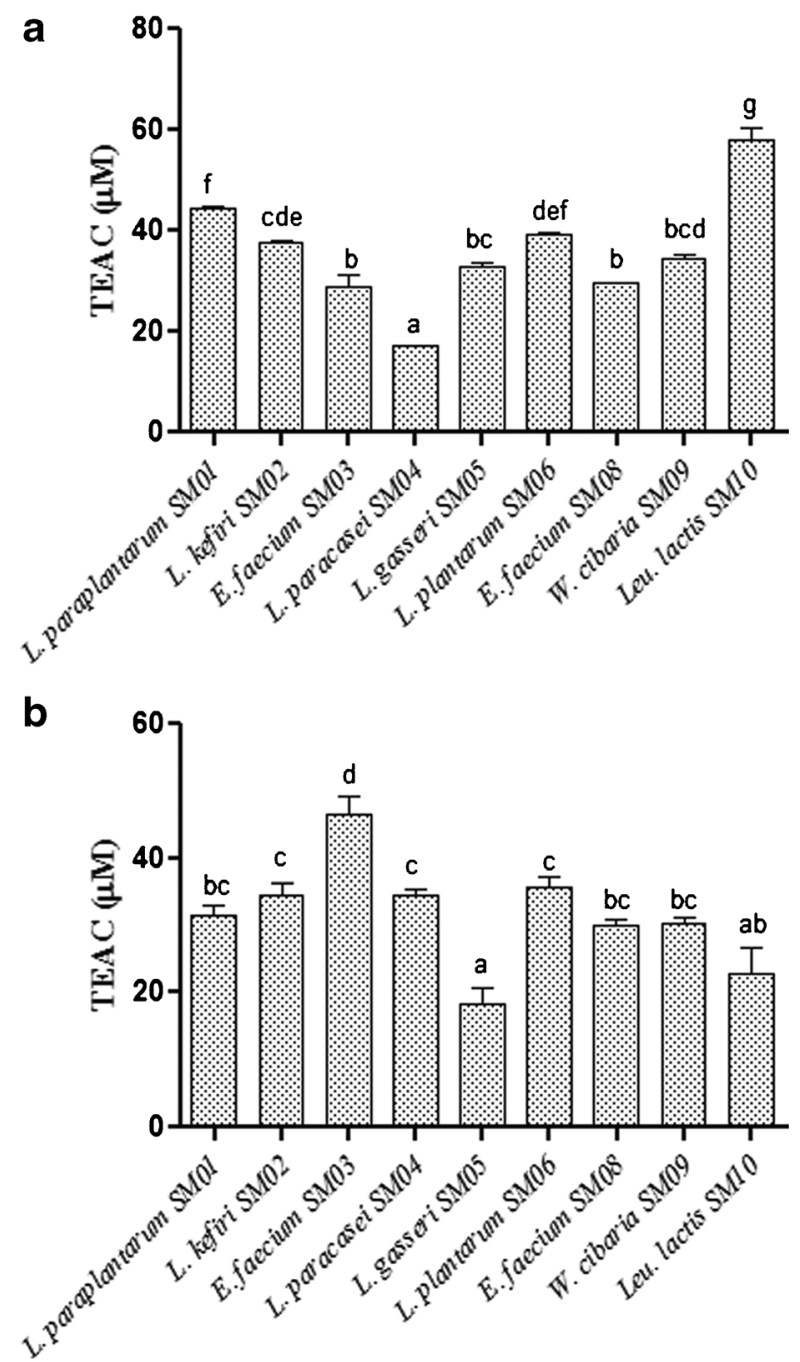

Fig. 4 DPPH radical-scavenging activity of whey fractions from fermented camel (a) and bovine (b) milks with single strains of lactic acid bacteria after $24 \mathrm{~h}$ of fermentation. The data measured as TEAC $(\mu \mathrm{M})$. Error bars show standard error of the mean of triplicate measurements of experiments. Mean values with different small are significantly different $(P<0.05)$ 

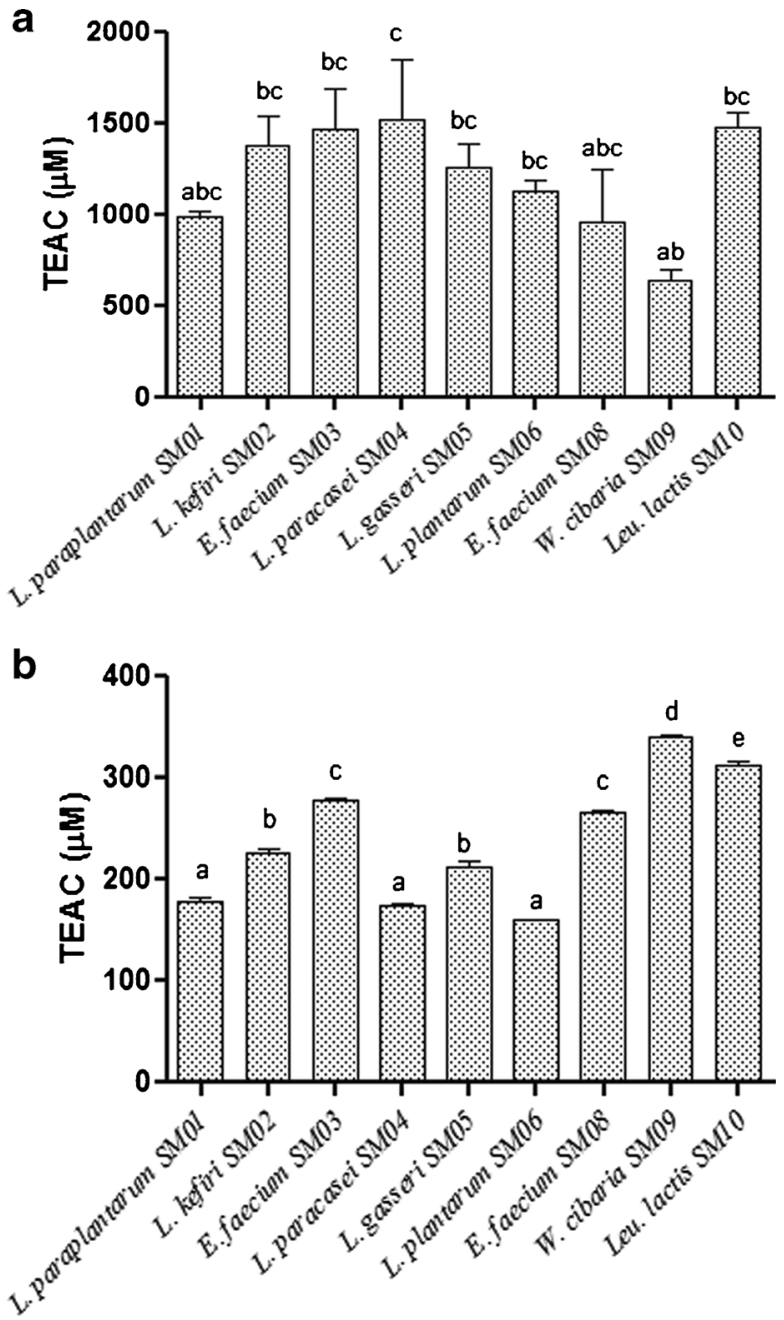

Fig. 5 ABTS radical scavenging activity of whey fractions from fermented camel (a) and bovine (b) milks with single strains of lactic acid bacteria after $24 \mathrm{~h}$ of fermentation. The data measured as TEAC $(\mu \mathrm{M})$. Error bars show standard error of the mean of triplicate measurements of experiments. Mean values with different small letters are significantly different $(P<0.05)$

\subsection{Sensory evaluation of fermented camel and bovine milks}

Twenty assessors were contributed to characterize sensory properties of fermented milks. The results indicated that the taste acceptance of fermented camel milk samples was ranged between $3.36 \pm 0.41$ and $1.72 \pm 0.40$ (Table 2). Camel milk fermented by Leu. lactis SM10 and L. gasseri SM05 had the highest score. The mean value for aroma acceptance of fermented camel milk samples was between $2.09 \pm 0.41$ and $3.57 \pm 0.45$. As in the previous results, fermentation of camel milk by Leu. lactis SM10 and L. gasseri SM05 was recorded with the highest scores. Camel milk fermented by L. kefiri SM02 had the lowest score in both taste and aroma acceptance $(P<0.05)$. The texture acceptance was rated between $2.81 \pm 0.61$ and $4.57 \pm 0.32$ for fermented camel milk samples (Table 2). Fermentation of camel milk by 


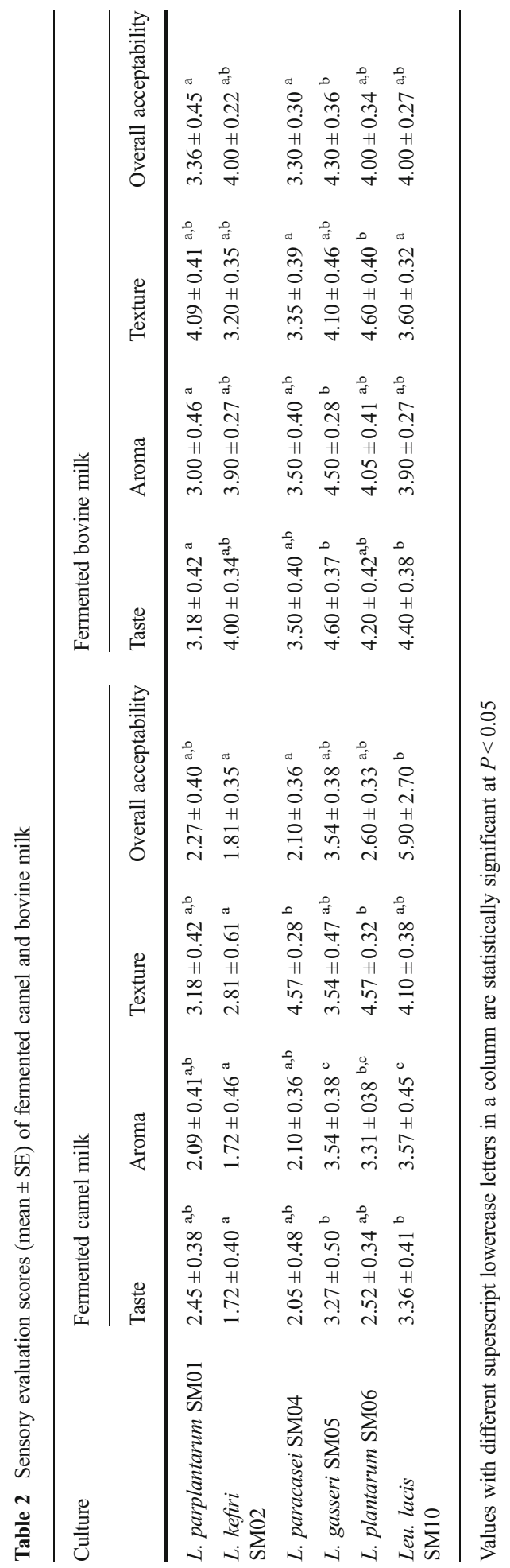


L. paracasei SM04 and L. plantarum SM06 had the highest score for texture acceptance, while the one fermented by L. kefiri SM02 had the lowest score. Camel milk fermented by Leu. lactis SM10 (5.90 \pm 2.70$)$ and L. kefiri SM04 (1.81 \pm 0.35$)$ had the highest and lowest overall acceptance values.

The taste acceptance of fermented bovine milk samples was rated between 3.18 \pm 0.42 and $4.60 \pm 0.37$. Bovine milk fermented by L. gasseri SM05 and Leu. lactis SM10 had the highest score while fermentation by L. plantarum SM01 had the lowest score for taste acceptance. The range of texture acceptance for fermented bovine milk samples was between $3.20 \pm 0.35$ and $4.60 \pm 0.40$ while the bovine milk fermented by L. plantarum SM06 had the highest score. The overall acceptance of fermented bovine milk samples was ranged between $3.30 \pm 0.30$ and $4.30 \pm 0.36$, and the sample fermented by L. gasseri SM05 had the highest score.

\section{Conclusion}

In this study, the fermentation of camel and bovine milk by LAB isolated from the Iranian traditional dairy product (Chal) under controlled conditions was investigated and the antioxidant activity of the whey fractions was evaluated. The antioxidant activity was measured by ABTS and DPPH free radical scavenging activities. It was demonstrated that the antioxidant activity of fermented camel milk was greater than that of bovine milk. On the basis of these results, several LAB strains showed ability to produce antioxidant activity by fermentation of both milk types. Strain Leu. lactis SM10 showed significantly high antioxidant activity $(P<0.05)$ after fermentation of camel and bovine milk by DPPH and ABTS radical scavenging activity with relatively good organoleptic properties. Isolation of the LAB from traditional fermented camel milk samples such as Chal and evaluation of the antioxidant activity and organoleptic properties of fermented milks by these isolates such as Leu. lactis SM10 could be useful for the development of new fermented milk products as functional food.

Acknowledgments The support of Iranian Research Organization for Science and Technology is gratefully acknowledged. The authors wish to thank Dr. Mahta Mirzaei for her help on this project, and we are grateful to PTCC (Persian Type Culture Collection) for help with the bacterial identification.

\section{Compliance with ethical standards}

Conflict of interest The authors declare that they have no conflict of interest.

Statement of human and animal rights This article does not contain any studies with human or animal subjects performed by any of the authors.

\section{References}

Abu-Taraboush HM, al-Dagal MM, al-Royli MA (1998) Growth, viability, and proteolytic activity of bifidobacteria in whole camel milk. J Dairy Sci 81(2):354-361

Abu-Tarboush HM (1996) Comparison of associative growth and proteolytic activity of yogurt starters in whole milk from camels and cows. J Dairy Sci 79(3):366-371. doi:10.3168/jds.S0022-0302(96)76373-7 
Agamy EIE (2009) Bioactive components in camel milk. In: Park YW (ed) Bioactive components in milk and dairy products. Wiley-Blackwell, Ames, Iowa, USA

Al haj OA, Al Kanhal HA (2010) Compositional, technological and nutritional aspects of dromedary camel milk. Int Dairy J 20(12):811-821, http://dx.doi.org/10.1016/j.idairyj.2010.04.003

Al-Saleh AA, Hammad YA (1992) Buffering capacity of camel milk. Egypt J Food Sci 20:85-97

AOAC (2002) Official Methods of Analysis. Arlington, VA, USA

Arici M, Bilgin B, Sagdic O, Ozdemir C (2004) Some characteristics of Lactobacillus isolates from infant faeces. Food Microbiol 21(1):19-24, http://dx.doi.org/10.1016/S0740-0020(03)00044-3

Bahobail AS, Ali AA, Alyan AA (2014) Effect of fermentation process on the improvement of nutrition value of camel milk. Int J Multidisciplinary Curr Res 2:78-82

Balakrishnan G, Agrawal R (2014) Antioxidant activity and fatty acid profile of fermented milk prepared by. Pediococcus pentosaceus J Food Sci Technol 51(12):4138-4142

Cheng CC, Nagasawa T (1986) Effect of peptides and amino acids produced by Lactobacillus casei in milk on the acid production of bifidobacteria. Jpn J Zootech Sci 55:339-349

Church FC, Swaisgood HE, Porter DH, Catignani GL (1983) Spectrophotometric assay using ophthaldialdehyde for determination of proteolysis in milk and isolated milk proteins1. J Dairy Sci 66(6):1219-1227. doi:10.3168/jds.S0022-0302(83)81926-2

EFSA (2007) Opinion of the scientific committee on introduction of a qualified presumption of safety (QPS) approach for assessment of selected microorganisms referred to EFSA. The EFSA Journal 587:1-16

Fitzgerald RJ, Murray BA (2006) Bioactive peptides and lactic fermentations. Int J Dairy Technol 59(2):118125. doi:10.1111/j.1471-0307.2006.00250.x

Gobbetti M, Minervini F, Rizzello CG (2004) Angiotensin I-converting-enzyme-inhibitory and antimicrobial bioactive peptides. Int J Dairy Technol 57(2-3):173-188. doi:10.1111/j.1471-0307.2004.00139.x

Hartree EF (1972) Determination of protein: a modification of the Lowry method that gives a linear photometric response. Anal Biochem 48(2):422-427

Hernandez D, Cardell E, Zarate V (2005) Antimicrobial activity of lactic acid bacteria isolated from Tenerife cheese: initial characterization of plantaricin TF711, a bacteriocin-like substance produced by Lactobacillus plantarum TF711. J Appl Microbiol 99(1):77-84

Kandler O, Weiss N (1986) Genus Lactobacillus Beijerinck 1901, 212 AL . In: Sneath PHA, Mair NS, Sharpe ME, Holt JG (eds) Bergey's manual of systematic bacteriology, vol 3. Williams and Wilkins, USA, pp 1029-1234

Karagul-Yuceer Y, Drake MA (2006) Sensory analysis of yogurt. In: Chandan RC, White CH, Kilara A, Hui YH (eds) Manufacturing yogurt and fermented milks. Blackwell Publishing, Oxford

Korhonen HJ (2009) Bioactive Components in Milk In: Young W. Park (ed) Bioactive Components in Milk and Dairy Products. 2009 edn. Wiley-Blackwell, Ames, Iowa, USA, pp 15-42

Korhonen H, Pihlanto A (2006) Bioactive peptides: production and functionality. Int Dairy J 16(9):945-960, http://dx.doi.org/10.1016/j.idairyj.2005.10.012

Leroy F, De Vuyst L (2001) Growth of the bacteriocin-producing Lactobacillus sakei strain CTC 494 in MRS broth is strongly reduced due to nutrient exhaustion: a nutrient depletion model for the growth of lactic acid bacteria. Appl Environ Microbiol 67(10):4407-4413

Lorenzen PC, Meisel H (2005) Influence of trypsin action in yoghurt milk on the release of caseinophosphopeptide-rich fractions and physical properties of the fermented products. International J Dairy Technol 58(2):119-124. doi:10.1111/j.1471-0307.2005.00195.x

Mills S, Ross RP, Hill C, Fitzgerald GF, Stanton C (2011) Milk intelligence: Mining milk for bioactive substances associated with human health. Int Dairy J 21(6):377-401, http://dx.doi.org/10.1016/j.idairyj. 2010.12.011

Mirzaei M, Mirdamadi S, Ehsani MR, Aminlari M, Hosseini E (2015) Purification and identification of antioxidant and ACE-inhibitory peptide from Saccharomyces cerevisiae protein hydrolysate. Journal of Functional Foods 19, Part A:259-268, http://dx.doi.org/10.1016/j.jff.2015.09.031

Moslehishad M, Ehsani MR, Salami M, Mirdamadi S, Ezzatpanah H, Naslaji AN, Moosavi-Movahedi AA (2013a) The comparative assessment of ACE-inhibitory and antioxidant activities of peptide fractions obtained from fermented camel and bovine milk by Lactobacillus rhamnosus PTCC 1637. Int Dairy J 29(2):82-87, http://dx.doi.org/10.1016/j.idairyj.2012.10.015

Moslehishad M, Mirdamadi S, Ehsani MR, Ezzatpanah H, Moosavi-Movahedi AA (2013b) The proteolytic activity of selected lactic acid bacteria in fermenting cow's and camel's milk and the resultant sensory characteristics of the products. Int J Dairy Technol 66(2):279-285. doi:10.1111/1471-0307.12017

Parrella A, Caterino E, Cangiano M, Criscuolo E, Russo C, Lavorgna M, Isidori M (2012) Antioxidant properties of different milk fermented with lactic acid bacteria and yeast. Int J Food Sci Technol 47(12): 2493-2502. doi:10.1111/j.1365-2621.2012.03127.x 
Pihlanto-Leppälä A (2000) Bioactive peptides derived from bovine whey proteins: opioid and ace-inhibitory peptides. Trends Food Sci Tech 11(9-10):347-356, http://dx.doi.org/10.1016/S0924-2244(01)00003-6

Re R, Pellegrini N, Proteggente A, Pannala A, Yang M, Rice-Evans C (1999) Antioxidant activity applying an improved ABTS radical cation decolorization assay. Free Radic Biol Med 26(9-10):1231-1237

Solieri L, Rutella GS, Tagliazucchi D (2015) Impact of non-starter lactobacilli on release of peptides with angiotensin-converting enzyme inhibitory and antioxidant activities during bovine milk fermentation. Food Microbiol 51:108-116, http://dx.doi.org/10.1016/j.fm.2015.05.012

Son S, Lewis BA (2002) Free radical scavenging and antioxidative activity of caffeic acid amide and ester analogues: structure-activity relationship. J Agric Food Chem 50(3):468-472

Torriani S, Felis GE, Dellaglio F (2001) Differentiation of Lactobacillus plantarum, L. pentosus, and L. paraplantarum by recA Gene Sequence Analysis and Multiplex PCR Assay with recA GeneDerived Primers. Appl Environ Microb 67(8):3450-3454. doi:10.1128/aem.67.8.3450-3454.2001

Virtanen T, Pihlanto A, Akkanen S, Korhonen H (2007) Development of antioxidant activity in milk whey during fermentation with lactic acid bacteria. J Appl Microbiol 102(1):106-115

Widyastuti Y, Rohmatussolihat, Febrisiantosa A (2014) The role of lactic acid bacteria in milk fermentation. Food Nutr Sci 5:435-442

Yamamoto N, Takano T (1999) Antihypertensive peptides derived from milk proteins. Nahrung 43(3):159164

Yoganandi J, Mehta BM, Wadhwani KN, Darji VB, Aparnathi KD (2014) Evaluation and comparison of camel milk with cow milk and buffalo milk for gross composition. J Camel Pract Res 21(2):259-265

Zhang S, Zhang L, Jiao Y, Luo X, Li H, Xin L, Xue C, Zhang Y, Yi H, Han X, Ma C (2014) Technological characterization of lactic acid bacteria protease isolated from traditional chinese fermented milk. J Food Quality 37(6):395-402. doi:10.1111/jfq.12115 